\title{
STANDARDS OF CULTURAL BEHAVIOUR OF THE ROMANS IN THE LIGHT OF SIDONIUS APOLLINARIS' LETTERS
}

\begin{abstract}
The cultural and political situation of the Gallo-Roman elite in the $5^{\text {th }}$ century $\mathrm{CE}$, during the period of the great barbarian invasions, became the reason for the emergence, among its members, of certain standards of behaviour; their aim was to preserve, cultivate and develop the Roman identity as well as a sense of belonging to the elite cultural circle, now endangered by barbaric chaos. The paper presents selected examples of such standards of behaviour in spheres both private and public; they serve as an exemplification of conscious actions and choices designed to preserve traditional Roman system of values.
\end{abstract}

KEY WORDS: otium, negotium, otium litteratum ac philosophicum, vita privata, vita publica, elite behaviour, Romanitas, lifestyle, cultural isolation, education, public career, cursus honorum, humanitas litterarum

At the end of the $4^{\text {th }}$ and the beginning of the $5^{\text {th }}$ century, before the incursions of the barbarians, Gaul was flourishing, both economically and culturally. ${ }^{1}$ The country's material wealth was accompanied by high artistic and intellectual culture, blossoming not only in great urban centres, such as Arles, hailed as the Gallic Rome, Bordeaux, Lyon, Vienne or Narbonne, but also in the mansions of the local aristocracy, where 
a specific form of a "villa culture" developed; it took on the form of organizing poetic declamations, commented readings from classical authors and debates, both philosophical and literary.

Sidonius Apollinaris, a poet and avid correspondent, was late antiquity's true homo litterarius. He lived in the $5^{\text {th }}$ century $(430-$ c. 486$)$, when the Roman rule was deeply destabilized. ${ }^{2}$ His literary oeuvre consists both of poetic works (published separately as carmina maiora et minora) as well as of an important collection of nine books of letters, often embellished with poetic additions. ${ }^{3}$ Sidonius' correspondence proves the existence of a special bond, born out of shared artistic and philosophical ideals, coloured with friendship, patriotism and the love for the beauty of cultural tradition. The exchange of letters, often containing the sender's own poetic works and prose declamations, was of crucial importance for cultivating these special connections in those dangerous and volatile times.

The letters of Sidonius let us see a glimpse of cultural behaviours and actions of the Gallo-Roman aristocrats, often marked with elite distance and disdain not only for the barbarian world (which was a cultural standard at the time), but also for the uneducated Romans, prone to cultural barbarization. The educated Gallo-Roman elite, consisting mainly of the members of senatorial families and local aristocratic and highofficial families, was deeply attached to the Roman state and traditional Latin culture and it held the old philosophical and artistic values in high regard. ${ }^{4}$ Thus it shared a feeling of a kind of alienation in the sea of evergrowing barbarian influence; this feeling made it even more important to cultivate close bonds with likeminded and similarly behaving individuals, even if this bond could only be propagated by correspondence. ${ }^{5}$ These people, regardless of their social connections (they all, after all, belonged to the aristocratic elite) were also bound by personal friendship, built on the foundation of common education and shared artistic ideals. $^{6}$

$2 \quad$ Cf. Courcelle 1948.

3 Cf. critical works on Sidonius: Allard 1930; Stevens 1933; Rutherford 1938; Loyen 1943; Anglade 1963; Gualandri 1979; Styka 2008b.

$4 \quad$ Cf. van Waarden, Kelly 2013.

5 Cf. Gradowicz-Pancer 1996.

6 Cf. Swoboda 1995. 
The cultural and political situation, in which the Gallo-Roman elite has found itself in the $5^{\text {th }}$ century, during the great barbarian invasions, resulted in the creation, within this society, of certain standards of behaviour, aimed at preserving, cultivating and developing Roman identity and the sense of belonging to the elite cultural sphere, connected with the great traditions of the Graeco-Roman culture and endangered by the barbaric chaos. This paper will present a number of such standards both in the public and private sphere; they will be an exemplification of the conscious actions and choices, designed to protect the traditional Roman system of values.

Let us start with the division of the civic activity into two spheres, well established within Roman culture. The first of them is negotium, connected with the whole set of actions, designed for the good of the country and consisting of actions in the public sphere of education, politics, law and the military; education is treated here as a preparation for the future civic duties. The second is otium, nominally connected with the private sphere, although often going beyond it, and consisting mainly of cultivating one's passions, interests and pleasures. This sphere would also contain writing literature and philosophy, otium litterarium et philosophicum. During the republic it seems pretty obvious that the elite would value negotium over otium; in the imperial times these were transformed, due to the change in the form of political activity, now subjected to the will of the emperor.

In late antiquity, in the provinces directly endangered by barbarian incursions, broadly understood cultural otium seems to have been valued over the limited negotium. This new evaluation of activities is clearly visible in the attempts of manifesting one's Roman identity and high regards for tradition. The old otium, understood as vita privata, now becomes a publicly engaged vita publica. Cultural and philosophical interests, expressed in writing poetry, undertaking philosophical studies, engaging in literary and critical discussions are of crucial importance here. All this done to keep the cultural network alive through epistolography.

The letters of Sidonius provide some valuable insights into the vast phenomenon of literary life in Gaul being a manifestation of the threatened Romanitas. The chief concept of the literary life, both in large urban centres and in the walled villas of aristocrats, was to keep the literary culture of Gaul, continuing traditional Roman culture, alive. The 
collegia poetarum were of special importance for this task. Apart from possibly the one in Arles in the times of emperor Majorian (457-461) they did not have an institutionalized, organized form; at the same time, however, they were very actively organizing frequent meetings for those interested in writing poetry, recitations, rhetorical declamations and philosophical disputes. ${ }^{7}$ It is surprising how high a level of intellectual culture was attained by these individuals, often high-ranking administrative and government officials, for whom the cultivating of literary tasks was not only a form of pleasant occupation in their spare time, personal selfimprovement or celebrating friendships according to old Roman otium tradition, but also, in many cases, a way of manifesting their Roman identity and love for the traditional culture. We may glimpse not only into the lively intellectual and literary exchanges of multi-genre poetry and prose in Arles, Lyon, Vienne, Prusianum, Narbonne or Bordeaux, but also a welcome atmosphere of late ancient literary salon in Gaul, permeated by the refined urbanitas, the cult of ancient Muses, aristocratic elite way of thinking, adoration for all things Roman and local patriotism.

Sidonius pays a lot of attention to the presentation of the ideal of literary communion as a feature of endangered Roman identity. The analogy to the ideal literary community of the neoteric poets in republican Rome is striking. We have here the same feeling of poetic self-consciousness, artistic and elite thinking and exclusivity, seen in the disdain for the crowd and addressing one's own works to the educated few. Sidonius calls an illiterate and ignorant crowd, no matter how large, a great loneliness: Ego turbam quamlibet magnam litterariae artis expertem maximam solitudinem appello. ${ }^{8}$ Another facet of this culture is providing friendly critical remarks, based on social associations and shared aesthetic values, to one's peers.

The new concept, without a direct equivalent in openly anesthetizing neoteric concepts, is a patriotic love for all things Roman, a strong belief in the immortality and continuous existence of Rome (Roma aeterna) ${ }^{9}$ and active striving to preserve the old way of life. Just like other highly

\footnotetext{
Cf. Styka 2015.

Cf. Epist.VII 14, 10.

Cf. Brodka 1997.
} 
educated members of the Gallo-Roman aristocracy, Sidonius did have an awareness of cultural decay, but understood in a quantitative, not qualitative way. Late ancient writers were conscious of the fact that there were indeed fewer and fewer people with perfect command of classical Latin remaining. Still, they valued their own education and erudition and they did not have any inferiority complex towards the artistic and literary achievements of the previous generations; they shared a firm belief that their own works are still of the same high quality.

The respect for old cultural traditions is also visible in their defence of attitudes towards the educational negotium. In Sidonius' writings, the feeling of elitist and uniqueness applied to his own works is accompanied by great benefits that other people take from the development of literary studies and passions: Esse tibi usui pariter et cordi litteras granditer gaudeo. ${ }^{10}$ As he writes in his letter to Ruricius, this kind of education provides a young man with proper preparation for a public career, as an orator with excellent style. A young rhetor with such an education would be able to take on difficult cases, which, while requiring considerate skill and work, can also make his famous: Nam moris est eloquentibus viris ingeniorum facultatem negotiorum probare difficultatibus. ${ }^{11}$

The prospects of getting education in $5^{\text {th }}$ century Gaul, especially in the second half of this century, were indeed seriously limited. ${ }^{12}$ The letters of Sidonius point, however, at a lively educational tradition even in this region, permanently endangered by barbarian invasions. The information he provided concerning the curriculum of the grammaticalrhetorical school of Eusebius in Arles (Eusebianos lares - Epist. IV 1) and the activities of Iohannes Grammaticus (Epist. VIII 2), started a discussion among scholars concerning the real condition of grammatical and rhetorical schools in $5^{\text {th }}$ century Gaul. Two contrary ideas are predominant. M. Roger, in his 1905 book, assumed that no public schools of various levels were functioning in the $5^{\text {th }}$ century, since there are no sources proving their existence; therefore Sidonius' comment must be interpreted as pertaining to the private home education (intra lares) of a limited group of students. Conversely, P. Riché, a well-known specialist

\footnotetext{
$10 \quad$ Cf. Epist. VIII 10, 1.

11 Cf. Epist. VIII 10, 2.

12 Cf. Styka 2008a.
} 
in the field of culture and education in late antiquity, remains convinced that the lack of sources does not prove the discontinuation of public schools' existence in Gaul, because there are some testimonies suggesting that in Gallic cities, numerous and varied public municipal institutions still existed up to the end of the $5^{\text {th }}$ century. Why would schools be an exception ? $^{13}$ Therefore, is seems quite probable that public education in Southern Gaul did exist up until the catastrophe of the year 474, when emperor Julius Nepos conceded almost all territories in Southern Gaul to the Visigoths, in a peace treaty with the Visigoth king Euric. The functioning of schools before that date could be surmised from Sidonius' letter VIII 2, written to the grammarian Iohannes and dated by Loyen to c. 478 , in which Sidonius enthusiastically complements the teacher. The author mentions that in the upcoming times of barbarian domination, when the external signs of dignity would be removed, only education would remain as a mark of nobility: nam iam remotis gradibus dignitatum, per quas solebat ultimo a quoque summus quisque discerni, solum erit posthac nobilitatis indicium litteras nosse. ${ }^{14}$

The letter seems to prove at least some limited existence of the grammatical-rhetorical schools in Southern Gaul in the last decades of the $5^{\text {th }}$ century, yet the youth of Sidonius was still the time when, notwithstanding the existing threats, Roman rule, at least in the Southern Gaul, did not seem endangered and the cities of the region could still develop their Latin culture. ${ }^{15}$ All of this allowed Sidonius to gain a good education, steeped in bilingual, Graeco-Roman cultural tradition. His literary erudition and mythological knowledge are not always very deep, but, taking the circumstances in which his poetry came to be into account, his works still count as refined and elegant. The poems are supported in the letters by Sidonius' firm defence of the purity of Latin against barbaric accretions and additions to the Latin language as well as by the elegance of

\footnotetext{
13 Cf. Riché 1957b: 421ff, also Downey 1976; Marrou 1978: 67ff.

14 Cf. Epist. VIII 2, 1.

15 Cf. Riché 1957a: 43-45. In this context it is also important to note the opinion of Ennodius, in the co-called Paraenesis didascalica in Dictiones. This prosometric lecture on the ways of getting an education contains a description of the crucial parts of the students' curriculum: grammar, rhetoric, poetics, law, dialectic and arithmetic. It proves that in the $5^{\text {th }} / 6^{\text {th }}$ century the traditional model of school education was still used.
} 
Sidonius' poetic diction. He shows a tendency to use carefully selected and artistically chiselled words, in the so called gemmeus stilus. ${ }^{16}$

One of the crucial consequences of cultivating the old Roman tradition of negotium was public activity, whose borders and limitations were, in imperial times, generally dictated by the will of the ruler. Despite numerous constraints, resulting from the fact that Rome at that time was, practically, a monarchy, certain opportunities either inherited from the republican past or created by the new regime were still open for the ambitions individuals ready to climb the ladder of their imperial and municipal career. There were new areas of public service opening in Roman provinces, with their double administration, imperial and local. The latter would, in turn, ensure that the local aristocracy would eagerly embrace the models of public activities once typical for the old nobilitas Romana.${ }^{17}$ A proper beginning for such a career and advancement would be not only the right social position, inherited from the ancestors, but also a profound education in rhetoric and philosophy, guaranteeing the future speaker a certainty in his public presentations. ${ }^{18}$

The letters of Sidonius Apollinaris more than once convincingly prove the social and political engagement of the author himself. In the letter I 3 Sidonius presents to his friend Philimatius, rather unwilling to take his place in the council of the prefecture of Gaul, two examples worth following. Firstly, he talks about himself, a man who belongs to a family which, for generations, has been holding highest imperial offices, both civil and military; despite that fact, he is still striving to achieve a hereditary patrician position, which would add even more splendour to his family name: I nunc et legibus me ambitus interrogatum senatu move, cur adipiscendae dignitati hereditariae curis pervigilibus incumbam; cui pater, socer, avus, proavus praefecturis urbanis praetorianisque, magisteriis Palatinis militaribusque miscuerunt. ${ }^{19}$

The second example is the case of a young Roman soldier, in the rank of tribune, name Gaudantius. Thanks to his ambitions, he managed to get the position of vicarius and became the second in command to the prefect of pretorium in Gaul. Thus he surpassed some much higher born

\footnotetext{
$16 \quad$ Cf. Roberts 1989.

17 Cf. Styka 2011: 303-318.

18 Cf. Brown 1992; Bowman, Wolf 1994.

19 Cf. Epist. I 3, 1.
} 
young aristocrats, who are now forced, due to their own indolence, to bow down and show respect to a person whom they disregarded before, whether they like it or not: Et ecce Gaudentius meus, hactenus tantum tribunicius, oscitantem nostrorum civium desidiam vicariano apice transcendit. Mussitat quidem iuvenum nostrorum calcata generositas, sed qui transiit derogantes in hoc solum movetur, ut gaudeat. Igitur venerantur hucusque contemptum ac subitae stupentes dona fortunae quem consessu despiciebant, sede suspiciunt. ${ }^{20}$

Conversely, in letter I 6, 2-3 Sidonius reminds his friend Eutropius that he possesses all the qualities necessary for the high imperial official: he is healthy, in his prime, wealthy, energetic in managing his own farm, he only lacks the courage to start a public service. And yet, a person like Eutropius, born to an old senatorial family, ${ }^{21}$ seeing the portraits of his toga-clad Roman ancestors every day, worldly and sophisticated, and one who already in his youth became familiar with Rome: the capital of the world, the cradle of law and the motherland of freedom, by all means should not lock himself away in his country estate, surrounded by simple people and dealing only with numerous country farmer's duties: Si tamen senatorii seminis homo, qui cotidie trabeatis proavorum imaginibus ingeritur, iuste dicere potest semet peregrinatum si semel et in iuventa viderit domicilium legum, gymnasium litterarum, curiam dignitatum, verticem mundi, patriam libertatum, in qua unica totius orbis civitate soli barbarii et servi peregrinantur. Et nunc, pro pudor, si relinquare inter busequas rusticanos subulcosque ronchantes! [...] Quin potius expergiscere et ad maiora se pingui otio marcidus et enervis animus attollat. Non minus est tuorum natalium viro personam suam excolere quam villam.22

This very letter could be of great importance for study of the evolution of the word negotium. What we observe here differs greatly from the old Roman views. Cultivating the agricultural interests (agricultura), which, as we must remember, is a basis for the Roman term for culture

20 Cf. Epist. I 3, 2.

21 Eutropius' great-grandfather was a consul of 316; on this, cf. Stevens 1933: 197; Stroheker 1948: 171.

22 Cf. Epist. I 6, 2-3. Sidonius' eulogy of old Rome is among the most enthusiastic ones in this period; one may compare it with the praise of another Gallo-Roman aristocrat of the same time, Rutilius Namatianus, in his work De reditu suo I 44-162. 
and has been canonized by Cato the Elder, Varro of Reate, Cicero, Virgil and others, has been treated by Sidonius with certain disdain. He added it, against the traditional mos maiorum, to the sphere of otium, understood as idleness and devoting one's time only to the private pleasures, hinting at egoism (otium pingue). According to Sidonius, agricultural tasks are proper only for veterans, who had already served their country in the military and now, in their old age, enjoy their well-earned rest in the country: Ad extremum, quod tu tibi iuventutis exercitium appellas, hoc est otium veteranorum, in quorum manibus effetis enses robiginosi sero ligone mutantur. ${ }^{23}$ This kind of occupation, however, cannot replace political activities, typical for the young age. If Eutropius would bury himself in the country and devote all his time and energy to the country life and work, and in doing so disregard a proper cursus honorum, typical for a young Roman aristocrat, he would lament his idleness in old age, when less worthy men would overtake him in getting public offices and he would have to accept their superiority in public meetings: Non nequiter te concilii tempore post sedentes censentesque iuvenes inglorium rusticum, senem stantem latitabundum pauperis honorati sententia premat, cum eos quos esset indignum si vestigia nostra sequerentur videris dolens antecessisse. ${ }^{24}$

The scope of the present paper does not allow us to recall numerous other instances where Sidonius either encourages his friends to undertake a public duty or present the example of such a service. It would be helpful, however, to quote two more such opinions. The first of them concerns individuals, who per fas et nefas are trying to gain popularity and respect of important citizens. In doing so they fulfil all the demeaning actions typical for clients; some of them even pretend to fulfil certain civic actions with great detriment to their own finances, their only reason being unhealthy ambition and the will to be known in public: Multi frequenter, quos execrabilis popularitas agit, civium maximos manu prensant, deque consessu publico abducunt ac sequestratis oscula impingunt, operam suam spondent, sed non petiti; itque videantur in negotii communis assertionem legari, evectionem refundunt ipsosque sumptus

$\begin{array}{ll}23 & \text { Cf. Epist. I 6, } 4 . \\ 24 & \text { Cf. Epist. I 6, } 4 .\end{array}$ 
ultro recusant et de ambitu clam rogant singulos, ut ab omnibus palam rogentur. ${ }^{25}$

The second example can be found in letter II 10, addressed to Hesperius. Its final part is very characteristic for the image of the politically engaged Roman humanitas litterarum in Sidonius' letters. It deals with the presence of women in typically men-developed and men-oriented academic and literary studies, which were often regarded as a base for the future public activity, by definition also typical for men. Sidonius urges Hesperius not to stop his literary studies and at the same time warns him against allowing his future wife to take him away from his reading. He reminds his reader about a number of female companions of well-known masters of Latin prose, who steadily supported their husbands in their literary and academic pursuits: Ecce parui tamquam iunior imperatis: tu modo fac memineris multiplicato me faenore remunerandum, quoque id facilius possis voluptuosiusque, opus est ut sine dissimulatione lectites, sine fine lecturias; neque patiaris ut te ab hoc proposito propediem coniunx domum feliciter ducenda deflectat, sisque oppido meminens quod olim Marcia Hortensio, Terentia Tullio, Calpurnia Plinio, Pudentilia Apuleio, Rusticiana Symmacho legentibus meditantibusque candelas et candelabras tenuerunt. ${ }^{26}$

This symbolic image of the wives holding candles over the heads of their husbands immersed in studies should not be understood literally. It is more fitting to read it in the context of respect, shown by Sidonius to well-educated females, who would not only support their husbands in their studies and readings, but also be their intellectual partners and oftentimes inspiring their work. ${ }^{27}$

The selected examples from Sidonius Apollinaris' letters presented here and showing the cultural attitude and practices of the Gallo-Roman aristocracy prove that in $5^{\text {th }}$ century Gaul, the same philosophical, academic and literary trends which formed Roman intellectual culture of the imperial period, were still alive. This late Roman culture would still be filled with classical themes and with the same well-known aspirations for a good general education, allowing one a good start in the public life

\footnotetext{
25 Cf.. Epist. V 20, 2.

26 Cf.. Epist. II 10, 5.

27 Cf. Bonjour 1988: 40-52, also Mascoli 2000: 89-107.
} 
and the development of an individual career. The crucial aim in these new times, however, is to preserve the Roman way of life and Roman lifestyle, endangered by barbarian invasions.

\section{REFERENCES}

Allard P., 1930 (19101), Sidoine Apollinaire, Paris.

Anglade J., 1963, Sidoine Apollinaire, Clermont-Ferrand.

Badel Ch., 2005, La noblesse de l'Empire Romain. Les masques et la vertu, Champ Vallon.

Bonjour M., 1988, 'Discrétion mondaine ou réserve chrétienne? Les femmes chez Sidoine Apollinaire', [in:] Hommages à Henri Le Bonniec, Res Sacrae, D. Porte, J.-P. Néraudau (eds.), Bruxelles, pp. 40-52.

Bowman A.K., Woolf G. (eds.), 1994, Literacy and Power in the Ancient World, Cambridge.

Brodka D., 1997, 'Die Idee der 'Roma Aeterna' in den Kaiserpanegyriken des Sidonius Apollinaris', Classica Cracoviensia 3, pp. 121-129.

Brown B., 1992, Power and Persuasion in Late Antiquity. Towards a Christian Empire, Madison.

Courcelle P., 1948, Histoire littéraire des grandes invasions germaniques, Paris.

Downey D., 1976, 'Erziehung und Bildung im spätrömischen Reich', [in:] Erziehung und Bildung in der heidnischen und christlichen Antike, H.Th. Johann (ed.), Darmstadt, pp. 549-572.

Gradowicz-Pancer N., 1996, "L'honneur oblige'. Esquisse d'une cartographie des conduites et des stratégies de l'honneur aux Ve et VI' siècles', Revue Belge de Philologie et d'Histoire 74(1), pp. 273-293, https://doi.org/10.3406/ rbph.1996.4106.

Grzywaczewski J., 2005, 'Roma, Romanitas, Christianitas u Sydoniusza Apollinarego', [in:] Kościół w życiu publicznym, vol. 3, S. Wielgus (ed.), Lublin, pp. 329-348.

Gualandri I., 1979, Furtiva lectio. Studi su Sidonio Apollinare, Milano.

Jones A.H.M., 1970 (1964'), The Later Roman Empire 284-602. A Social, Economic and Administrative Survey, Oxford.

Loyen A., 1943, Sidoine Apollinaire et l'esprit précieux en Gaule aux derniers jours de l'empire, Paris. 
Marrou H.-I., 1978, L'école de l'antiquité tardive, [in:] H.-I. Marrou, Christiana Tempora. Mélanges d'histoire, d'archéologie, d'épigraphie et de patristique, Paris, pp. 67-77.

Mascoli P., 2000, 'Personnagi feminili in Sidonio Apollinare', Invigilata lucernis 22, pp. 89-107.

Riché P., 1957a, 'La fin des écoles publiques en Gaule en Ve siècle', Bulletin de la Societé nationale des Antiquaires de France, pp. 43-45, https://doi. org/10.3406/bsnaf.1959.5657.

Riché P., 1957b, 'La survivance des écoles publiques en Gaule au Ve siècle', Le Moyen Âge 63, pp. 421-443.

Roberts M., 1989, The Jeweled Style. Poetry and Poetics in Late Antiquity, Ithaca-London.

Rutherford H., 1938, Sidonius Apollinaris. L'homme politique, l'écrivain, l'éveque. Étude d'une figure gallo-romaine du V siècle, Clermont-Ferrand (diss.).

Stevens C.E., 1933, Sidonius Apollinaris and His Age, Oxford.

Stroheker K.F., 1948, Der senatorische Adel im spätantiken Gallien, Tübingen.

Styka J., 2008a, 'Römische Schule der Spätantike im Lichte der Briefe von Sidonius Apollinaris', Classica Cracoviensia 12, pp. 157-175.

Styka J., 2008b, Sydoniusz Apollinaris i kultura literacka w Galii Vwieku, Kraków.

Styka J., 2011, “Cursus honorum’ im spätantiken Gallien im Lichte der Briefe von Sidonius Apollinaris', Classica Cracoviensia 14, pp. 303-318.

Styka J., 2015, 'Late Ancient 'Collegia poetarum' According to Sidonius Apollinaris', Classica Cracoviensia 18, pp. 377-390, https://doi.org/10.12797/ CC.18.2015.18.22.

Swoboda A., 1995, Pojęcie przyjaźni w listach św. Paulina z Noli i św. Sydoniusza Apolinarego. Studium porównawcze, Poznań.

Waarden van J.A., Kelly G. (eds.), 2013, New Approaches to Sidonius Apollinaris, Leuven. 